\title{
Hubungan Pengetahuan dengan Sikap Masyarakat dalam Pencegahan Penyakit Demam Berdarah Dengue di Desa Betalemba Kecamatan Poso Pesisir Selatan
}

\author{
Knowledge Relationship with Community Attitudes in Prevention of Dengue Hemorrhagic \\ Fever in Betalemba Village, Poso Pesisir Selatan District
}

\author{
Anggri Assa \\ Sekolah Tinggi Ilmu Kesehatan Husada Mandiri Poso \\ Email : anggri_assa87@yahoo.com
}

\begin{abstract}
Background: Dengue Hemorrhagic Fever (DHF) is one of many infectious diseases caused by the bite of the Aedes aegypti mosquito which is commonly found in tropical and subtropical regions throughout the world. This disease can occur throughout the year and attack every individual regardless of age. This disease appears related to environmental conditions and community behavior. Research Methods: This research is a quantitative type with a correlation design and cross sectional approach. The population is all the communities in the village of Betalemba with 303 families. Until that is a portion of the population of 171. The sampling technique is proportional stratified random sampling. The data were analyzed and tested using the Chi-Square test with a value of $\mathrm{P}<0.05$. Results: showed 83 respondents $(38.8 \%)$ were sufficiently knowledgeable, 68 knowledgeable respondents (39.8\%) and 20 (11.7\%) less knowledgeable respondents, then respondents who had enough attitudes 105 (61.4\%), respondents who have good attitudes as much as 53 (31.0\%) and respondents who have less attitudes as much as $13(7.6 \%)$. Conclusion: Knowledge relates to people's attitudes in preventing dengue disease in Betalemba village, Poso Pesisir Selatan District.
\end{abstract}

Keywords: Knowledge, Attitude, DHF

\begin{abstract}
Abstrak
Latar Belakang : Demam Berdarah Dengue (DBD) merupakan satu dari sekian banyak penyakit infeksi yang disebabkan oleh gigitan nyamuk Aedes aegypti yang banyak ditemui di daerah yang beriklim tropis dan subtropis di seluruh dunia. Penyakit ini dapat terjadi sepanjang tahun dan menyerang setiap individu tanpa memandang umur. penyakit ini muncul berkaitan dengan kondisi lingkungan dan perilaku masyarakat. Metode Penelitian: Penelitian ini berjenis kuantitatif dengan desain korelasi dan pendekatan cross sectional. Populasi adalah semua masyarakat di desa Betalemba sebanyak 303 kepala keluarga. Sampe yaitu sebagian dari populasi sebanyak 171. Teknik pengambilan sampel dengan cara proporsionate stratified random sampling. data dianalisis dan diuji dengan menggunakan uji Chi-Square dengan nilai $\mathrm{P}<0,05$. Hasil Penelitian: menunjukkan responden yang berpengetahuan cukup sebanyak 83 $(38,8 \%)$, responden yang berpengetahuan baik sebanyak $68(39,8 \%)$ dan responden yang berpengetahuan kurang sebanyak $20(11,7 \%)$, kemudian responden yang memiliki sikap cukup sebanyak $105(61,4 \%)$, responden yang memiliki sikap baik sebanyak $53(31,0 \%)$ dan responden yang memiliki sikap kurang sebanyak $13(7,6 \%)$. Kesimpulan: Pengetahuan berhubungan
\end{abstract}


dengan sikap masyarakat dalam mencegah penyakit DBD di desa Betalemba Kecamatan Poso Pesisir Selatan.

Kata Kunci : Pengetahuan, Sikap, DBD

\section{LATAR BELAKANG}

Demam Berdarah Dengue (DBD) merupakan satu dari sekian banyak penyakit infeksi yang disebabkan oleh gigitan nyamuk Aedes Aegipty yang banyak ditemui di daerah yang beriklim tropis dan subtropis di seluruh dunia. Penyakit ini dapat terjadi sepanjang tahun dan menyerang setiap individu tanpa memandang umur. penyakit ini muncul berkaitan dengan kondisi lingkungan dan perilaku masyarakat (1).

Di Indonesia pada tahun 2008 mencapai angka 137.469 kasus dengan kasus yang menyebabkan kematian sebanyak 1187 orang. pada tahun 2009 kasus DBD meningkat mencapai 158.912 kasus,dengan jumlah kematian sebanyak 1420 orang. kemudian pada tahun 2010, trjadi penurunan kasus DBD menjadi 156.806 kasus dengan jumlah kematian sebanyak 1358 orang (2). Pemerintah Kabupaten Poso Sulawesi tengah pada tahun 2016 menetapkan sebagai daerah wilayah dengan status Kejadian Luar Biasa (KLB) untuk penyakit Demam Berdarah Dengue (DBD). Dalam bulan Oktober- Januari tercatat sudah ada 153 kasus terjadi. Dari jumlah itu tiga orang di antaranya di laporkan meninggal dan tersebar di tiga Kecamatan yang berbeda, masingmasing warga desa Tokorondo Kecamatan poso Pesisir, desa Kayamanya Kecamatan Poso Kota dan desa Sangira Kecamatan Pamona Utara. Saat ini di Poso penyebaran penyakit DBD sudah mewabah di delapan kecamatan yakni Poso Kota, Poso Kota Utara, Poso Kota Selatan, Poso Pesisir, Poso Pesisir Utara, Poso Pesisir Selatan, Lage dan Kecamatan Pamona Utara (3).

Kurangnya pengetahuan tentang DBD dapat mempengaruhi tindakan pencegahan yang dilakukan oleh masyarakat dimana pengetahuan atau kognitif merupakan domain yang sangat penting untuk terbentuknya tindakan seseorang (4). Tingkat pengetahuan yang dimiliki masyarakat mengenai pencegahan DBD akan mempengaruhi sikap terutama dalam hal mengambil keputusan dalam berperilaku. Sikap yang dimiliki seseorang dalam hal pencegahan DBD merupakan hal yang sangat penting karena ketika seseorang memiliki pengetahuan dan pengalaman tentang DBD yang cukup, maka seseorang tersebut cenderung akan memiliki keyakinan dan melakukan suatu upaya untuk mencegah terjadinya DBD. (5)

Pada penelitian yang dilakukan oleh Asgar (2009) menemukan adanya hubungan antara pengetahuan tentang DBD dengan perilaku menguras Bak Mandi, Menutup tempat 
penampungan air, mengubur barang bekas (3M) pada keluarga di Kelurahan Banguntapan Yogyakarta. Dimana seperti dikehui bahwa 3M merupakan tindakan yang harus dilakukan untuk mencegah DBD. (6)

\section{METODE PENELITIAN}

penelitian ini menggunakan metode kuantitatif dengan desain korelasi dan dilakukan dalam satu waktu (cross sectional). Populasi adalah semua masyarakat di desa Betalemba sebanyak 303 kepala keluarga. Sampe yaitu sebagian dari populasi sebanyak 171. Pengambilan sampel dengan cara proporsionate stratified random sampling. Data dianalisis dengan uji Chi-Square dengan batas kemaknaan $\alpha=0,05$.

\section{HASIL PENELITIAN}

\begin{tabular}{ccc} 
Tabel 1. Distribusi Frekuensi Responden Berdasarkan Umur di Desa Betalemba \\
Kecamatan Poso Pesisir Selatan \\
\hline Umur & Frekuensi (f) & Persentase (\%) \\
\hline $19-35$ & 77 & 45.0 \\
$36-50$ & 71 & 41.5 \\
$51-72$ & 23 & 13.5 \\
total & 171 & 100 \\
\hline
\end{tabular}

Pada Tabel 1 menunjukan bahwa sebagian besar responden berada pada rentang umur 19-35 tahun dengan jumlah 77 orang $(45, \%)$, dan responden yang paling sedikit berada pada rentang umur 51-72 tahun yaitu sebanayak 23 (13,5\%) orang.

Tabel 2. Distribusi Frekuensi Responden berdasarkan Jenis Kelamin di Desa Betalemba Kecamatan Poso Pesisir Selatan

\begin{tabular}{ccc}
\hline Jenis Kelamin & Frekuensi (f) & Persentase (\%) \\
\hline Laki-laki & 79 & 46.2 \\
Perempuan & 92 & 53.8 \\
Total & 171 & 100 \\
\hline
\end{tabular}


Pada Tabel 2 menunjukan bahwa dari responden terbanyak memiliki jenis kelamin perempuan yaitu sebanyak 92 orang $(53,8 \%)$ sedangkan yang berjenis kelamin laki-laki berjumlah 79 orang $(46,2 \%)$

Tabel 3 Distribusi Frekuensi Responden Berdasarkan Pendidikan di Desa Betalemba Kecamatan Poso Pesisir Selatan

\begin{tabular}{ccc}
\hline Pendidikan & Frekuensi (f) & Persentase (\%) \\
\hline SD & 45 & 26.3 \\
SMP & 45 & 26.3 \\
SMA & 61 & 35.7 \\
D3 & 9 & 5.3 \\
S1 & 11 & 6.4 \\
Total & 171 & 100 \\
\hline
\end{tabular}

Pada Tabel 3 menunjukan sebagian besar responden memupnyai tingkat pendidikan yaitu SMA dengan jumlah 61 orang $(35,7 \%)$ responden, dan sebagian kecil responden memiliki tingkat pendidikan D3 dengan jumlah 9 orang $(5,3 \%)$.

Tabel 4 Distribusi Frekuensi Responden Berdasarkan tingkat Pengetahuan Tentang Penyakit DBD di Desa Betalemba Kecamatan Poso PesisirSelatan

\begin{tabular}{ccc}
\hline Pengetahuan & Frekuensi (f) & Persentase (\%) \\
\hline Baik & 68 & 39.8 \\
Cukup & 83 & 48.5 \\
Kurang & 20 & 11.7 \\
Total & 171 & 100 \\
\hline
\end{tabular}

Pada Tabel 4 menunjukkan sebagian besar responden memiliki pengetahuan yang cukup tentang DBD yaitu sebanyak 83 orang $(48,5 \% \%)$, responden dengan pengetahuan baik sebanyak 68 orang $(39,8 \%)$ dan 20 orang $(11.7 \%)$ yang memiliki pengetahuan kurang.

\section{Tabel 5}

Distribusi Frekuensi Sikap Responden Dalam Pencegahan Penyakit DBD di Desa Betalemba Kecamatan Poso Pesisir Selatan

\begin{tabular}{ccc}
\hline Sikap & Frekuensi (f) & Persentase (\%) \\
\hline Baik & 53 & 31.0 \\
Cukup & 105 & 61.4 \\
Kurang & 13 & 7.6 \\
Total & \multicolumn{1}{c}{171} & 100 \\
\hline
\end{tabular}


pada Tabel 5 sebagian besar responden memiliki sikap yang cukup dalam pencegahan penyakit DBD, yaitu sebanyak 105 orang (61.4\%), selanjutnya sebanyak 53 orang (31.0\%) responden memiliki sikap baik dalam pencegahan penyakit DBD dan 13 orang (7.6\%) yang memiliki sikap kurang dalam pencegahan penyakit DBD..

Tabel 6 Hubungan Pengetahuan Dengan Sikap Responden Dalam Pencegahan Penyakit DBD di Desa Betalemba Kecamatan Poso Pesisir Selatan

\begin{tabular}{|c|c|c|c|c|c|c|c|c|c|}
\hline \multirow{3}{*}{ Pengetahuan } & \multicolumn{6}{|c|}{ Sikap } & \multirow{2}{*}{\multicolumn{2}{|c|}{ Total }} & \multirow[b]{3}{*}{$p$-value } \\
\hline & \multicolumn{2}{|c|}{ Baik } & \multicolumn{2}{|c|}{ Cukup } & \multicolumn{2}{|c|}{ Kurang } & & & \\
\hline & $\mathbf{f}$ & $\%$ & $\mathbf{f}$ & $\%$ & $\mathbf{F}$ & $\%$ & f & $\%$ & \\
\hline Baik & 25 & 14.6 & 44 & 25.7 & 0 & 0.0 & 69 & 40.4 & 0,000 \\
\hline Cukup & 25 & 14.6 & 52 & 30.4 & 3 & 1.8 & 80 & 46.8 & \\
\hline Kurang & 3 & 1.8 & 8 & 4.7 & 11 & 6.4 & 22 & 12.9 & \\
\hline Total & 53 & 31.0 & 104 & 60.8 & 14 & 8.2 & 171 & 100 & \\
\hline
\end{tabular}

Berdasarkan tabel 6 di atas menunjukan bahwa dari 69 responden (40,4 \%) yang berpengetahuan baik terdapat 25 responden (14,4\%) yang memiliki sikap yang baik dan 44 responden $(25,7 \%)$ yang memiliki sikap yang cukup dalam pencegahan penyakit DBD. kemudian dari 80 responden $(46,8 \%)$ yang berpengetahuan cukup terdapat 25 responden $(14,6 \%)$ yang memiliki sikap yang baik, 52 responden (30,4 \%) yang memiliki sikap yang cukup, dan 3 responden $(1,8 \%)$ yang memiliki sikap yang kurang dalam dalam pencegahan penyakit DBD. selanjutnya dari 22 responden $(12,9 \%)$ yang memiliki pengetahuan kurang terdapat 3 responden $(1,8 \%)$ yang memiliki sikap yang baik, 8 responden $(4,7 \%)$ memiliki sikap yang cukup, 11 responden $(6,4 \%)$ yang memiliki sikap kurang dalam pencegahan penyakit DBD. Hasil analisis menggunakan statistik Chi-Square di diperoleh nilai $\mathrm{p}=0,00(\mathrm{p}<0,05))$. hal ini menunjukkan adanya hubungan antara pengetahuan dengan sikap masyarakat dalam pencegahan penyakit DBD di desa Betalemba Kecamatan Poso Pesisir Selatan.

\section{PEMBAHASAN}

Berdasarkan hasil penelitian ini menunjukan adanya hubungan pengetahuan dengan sikap masyarakat dalam pencegahan penyakit DBD di Desa Betalemba Kecamatan Poso Pesisir Selatan. Hasil penelitian ini didukung oleh penelitian yang dilakukan oleh Rosdiana pada tahun 2010 dimana dalam penelitiannya menunjukkan adanya hubungan antara pengetahuan, sikap dan perilaku dengan pelaksanaan pemberantasan sarang nyamuk demam berdarah (DBD). (7) 
Pengetahuan yang dimiliki masyarakat hingga ke individu tentang penyakit DBD merupakan hal yang sangat penting. Pengetahuan yang rendah tentang penyakit DBD dapat berhubungan dengan munculnya resiko terkena DBD. Dengan demikian, jika keluarga khususnya memiliki pengetahuan yang cukup mengenai DBD, maka dapat terhindar dari risiko terkena DBD. Pengetahuan atau kognitif merupakan salah satu domain yang sangat penting dalam hal terbentuknya tindakan seseorang (8), dalam hal pencegahan DBD, pengetahuan tentang pencegahan penyakit DBD merupakan salah satu unsur terbentuknya tindakan seseorang dalam melakukan pencegahan DBD yang kemudian akan mencegah terjadinya penyakit tersebut. (9). Penelitian ini juga sejalan dengan penelitian yang dilakukan oleh Rahmaditia (2011) dimana pada penelitiannya menemukan adanya hubungan antara sikap terhadap tindakan pencegahan DBD. (10). WHO menyatakan bahwa salah satu alasan pokok dimana seseorang menunjukkan sikap dalam hubungannya dengan kesehatan adalah sosio budaya (culture) yang sangat berpengaruh terhadap terbentuknya sikap dan perilaku seseorang. (11)

Berdasarkan hasil yang telah di peroleh peneliti yang menunjukan bahwa terdapat hubungan pengetahuan dengan sikap masyarakat dalam pencegahan penyakit DBD di Desa Betalemba Kecamatan Poso Pesisir Selatan hal tersebut di sebabkan karena dengan pengetahuan yang di miliki oleh responden maka hal ini akan mendorong responden untuk lebih meningkatkan sikap dan perilaku dalam pencegahan penyakit DBD. Dengan pengetahuan yang baik yang di miliki oleh responden hal ini mungkin di sebabkan oleh banyaknya informasiinformasi yang mereka peroleh baik dari media cetak, televisi, radio dan internet, aktifnya petugas kesehatan dalam memberikan penyuluhan mencegah penyakit DBD dan lain sebagainya. Dalam melakukan penelitian peneliti mendapat hambatan yaitu adanya dua orang yang tidak bersedia untuk menjadi responden, hal ini di sebabkan karena kesibukan yang mereka miliki sehingga merasa tidak memiliki kesempatan untuk mengisi kuesioner yang telah ada.

\section{KESIMPULAN}

Berdasarkan hasil penelitian maka dapat disimpulkan sebagai berikut : (a) terdapat hubungan pengetahuan masyarakat tentang penyakit DBD dengan sikap masyarakat dalam pencegahan penyakit DBD. (b) sebagian besar responden memiliki pengetahuan cukup tentang penyakit DBD. (c) sebagian besar responden memiliki sikap yang baik dalam upaya pencegahan penyakit DBD. 


\section{DAFTAR PUSTAKA}

1. World Health Organization. Dengue and Severe dengue. 2012

2. Depkes RI. Pemberantasan Sarang Nyamuk Demam Berdarah Dengue (PSN DBD). Jakarta Depkes RI. 2007

3. Dinas Kesehatan Kabupaten poso. Informasi Data Kesehatan. 2016

4. Notoatmodjo S. Kesehatan Masyarakat Ilmu dan Seni. Revisi ed. Jakarta: Rineka Cipta; 2011.

5. Peristiowati Yuly, Kusumawardani L, Haryono. Evaluasi Pemberantasan Demam Berdarah Dengue dengan Metode Spasial Geographic Information System (GIS) dan Identifikasi Tipe Virus Dengue di Kota Kediri. Jurnal Kedokteran Brawijaya. 2014

6. Asgar, Lalu Haeluman., Isnaeni, Yuli. hubungan antara pengetahuan tentang DBD dengan perilaku 3M pada keluarga di Kelurahan Banguntapan Bantul Yogyakarta. 2009

7. Rosdiana. Hubungan Tingkat Pengetahuan, Sikap dan Perilaku dalam Pemberantasan Sarang Nyamuk Demam Berdarah Dengue di RT 02 Desa Lao Janan ulu Wilayah Kerja Puskesmas Lao Janan KabupatenKutai Kartanegara, Provinsi Kalimantan timur. Universitas Sebelas Maret. 2010.

8. Notoatmodjo S. Kesehatan Masyarakat Ilmu dan Seni. Revisi ed. Jakarta: Rineka Cipta; 2011.

9. Sianipar, R, Kapantow, N, Kaunang, W. Hubungan Antara Pengetahuan dan Sikap Masyarakat dengan Tindakan Pencegahan Demam Berdarah Dengue di Desa Warembungan Kecamatan Pineleng Kabupaten Minahasa. Fakultas Kesehatan Masyarakat Universitas Sam Ratulangi Manado. 2015

10. Rahmaditia, Tyas. Hubungan Pengetahuan dan Sikap Ibu Terhadap Tindakan Pencegahan Demam Berdarah Dengue Pada Anak di Wilayah Kerja Puskesmas Tlogosari Wetan Kota Semarang. 2011

11. World Health Organization. Demam Berdarah Dengue, ECG: Jakarta pustaka. 2005 